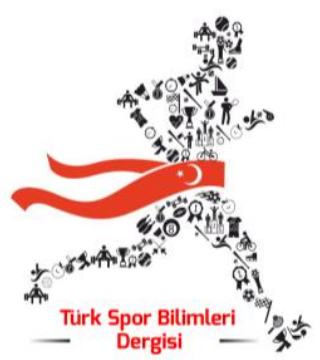

ISSN: 2636-848X

DOI: $10.46385 /$ tsbd. 872883

\section{Türk Spor Bilimleri Dergisi}

Türk Spor Bil Derg

Cilt 4, Sayı 2 Ekim 2021, 51-59

The Journal of 'Turkish Sport Sciences J Turk Sport Sci October 2021,51-50

Gökçe $A K G \ddot{U} \mathbf{N}^{1}$

${ }^{1}$ İstanbul Üniversitesi Cerrahpaşa Lisansüstü Eğitim Enstitüsü

Sorumlu Yazar/Corresponding Author: G. Akgün e-mail: gokceakgun@ogr.iuc.edu.tr

Gelis Taribi: 02.02.2021

Kabul Taribi: 19.09.2021

\title{
Artistik Yüzmeye Uyarlanan Don Quixote Balesinin Koreografi Analizi
}

\section{Özet}

Bu çalıșmada bale eserlerinin artistik yüzme sporuna uyarlanmasında gereken temel özelliklerin belirlenmesi amaçlanmıștır. Seçilen Don Quixote balesinin artistik yüzme yarıșma koreografisine uyarlanmasında dikkat çeken noktaların ortaya çıkarılması hedeflenmiş ve hazırlanan örnek çalışmayla günümüzde bale sanatının kullanım alanının genişlemesinde artistik yüzme sporunun etkisini ortaya çıkarmak amaçlanmıştır. Bale eserinin artistik yüzmeye uyarlanması hareket, mimik ve Don Quixote balesi özelinde değerlendirilmiștir. Araştırma grubunu Don Quixote konulu artistik yüzme ve bale koreografileri oluşturmaktadır. Artistik yüzme ve bale koreografileri, canlı performans kayıtları üzerinden süresine göre sürekli gözlem yapılarak hareketler açısından analiz edilmiștir. Artistik yüzme koreografisi analizi için seçilen müzikler ve Don Quixote balesinde kullanıldığı yerler belirlenmiştir. Her müzik bölümünün önce bale sonra artistik yüzme koreografisi incelenerek benzerlik ve farklılıklar saptanmıstır. Artistik yüzmeye uyarlanan Don Quixote balesindeki karakteristik kol hareketleri ve pozlar çok az kısıtlılıkla aktarılmıştır. Bacak hareketleri artistik yüzmenin baş aşağı hareket etme özelliğinden dolayı baledekine benzer şekilde uygulanamamıștır. Bale konulu bir eserin artistik yüzmeye uyarlanması sırasında müzik seçimine, karakteristik kol ve bacak hareketlerine, anlık pozlara ve duyguları anlatan mimik canlandırmalarına dikkat edilmesi gerekmektedir.

Anahtar Kelimeler: Artistik yüzme, bale, Don Quixote, koreografi analizi

\section{Choreography Analysis of The Don Quixote Ballet Adapted for Artistic Swimming}

\section{Abstract}

In this study, it is aimed to determine the basic characteristics required for the adaptation of ballet works to artistic swimming. It is aimed to display the remarkable points in the adaptation of the selected Don Quixote ballet to the artistic swimming competition choreography and the sample study prepared, it is revealed the effect of artistic swimming in the expansion of the usage area of ballet art today. The adaptation of the ballet work to artistic swimming has evaluated in terms of movement, gestures, and Don Quixote ballet. The research group consists of artistic swimming and ballet choreographies on Don Quixote. Artistic swimming and ballet choreographies were analyzed in terms of movements by making continuous observations over their live performance records. The music chosen for artistic swimming choreography analysis and their use in Don Quixote ballet determined. Similarities and differences determined by analyzing first ballet and then artistic swimming choreography of each music department. Almost all of the characteristic arm movements and poses in the Don Quixote ballet adapted for artistic swimming have conveyed. Leg movements have little similar to that of ballet because of the upside-down characteristic of artistic swimming. In the adaptation of a ballet-themed works to artistic swimming, should pay attention to music, characteristic arm, and leg movements, poses and gestures.

Keywords: Artistic swimming, ballet, Don Quixote, choreographic analysis

Atıf için; Akgün, G. (2021) Artistik yüzmeye uyarlanan Don Quixote balesinin koreografi analizi. Türk Spor Bilimleri Dergisi, 4(2), 51-59. 


\section{GİRİ̧̧}

Bale eserleri ilk sahnelendikleri dönemden itibaren tarih boyunca popüler sanatsal etkinlikler olmuşlardır. Sahnede üstün bir beceri gerektiren bale, günümüzde aynı özelliğini sürdürmektedir. Bale tarihinde bazı bale eserlerinin diğerlerinden daha popüler olduğu bilinmektedir. Teknik ve sanatsal açıdan bu eserlerin bale tarihine olumlu katkıları olmuş olup içerikleriyle ilgili çeşitli çalışmalar yapılmıştır (PanebiancoWarrens, 2014). Balenin farklı alanlardaki etkileri incelendiğinde bale eserlerinin önemi büyüktür. Son yıllarda önemli bale eserleri ve balenin teknik özellikleri pek çok alanda kullanılmaktadır. Spor alanında da bazı branşlarda bale tekniğinin ve eserlerinin kullanıldığı görülmektedir. Günümüzde sanatsal içerikli spor branşları, artistik unsurlarının büyük bölümünü sahne sanatları alanından esinlenerek oluşturmaktadır. Bale eserleri gerek estetik özelliği gerek müzikle etkili uyumu açısından bu alanda temel sanat dalı olma özelliğini taşımaktadır.

Sanatsal içerikli sporlar arasında yer alan artistik yüzme bir bakıma balenin suya uyarlanmış hâli olarak dikkat çekmektedir. Artistik yüzme, senkronize yüzme veya su balesi isimleriyle de bilinmektedir (Sydnor, 1998; FINA, 2017). En sanatsal spor dallarından biri olarak gösterilen artistik yüzme, olimpik bir spor olup yapı bakımından yüzme ve balenin birleşimi şeklinde gelişmiştir. FINA (Fédération Internationale de Natation)'ya bağlı spor dallarından biridir. Yapı itibariyle artistik yüzme yarışmaları belirli kurallar dahilinde hazırlanan koreografilerin müzikle uyumlu bir şekilde sunulmasıyla gerçekleşmektedir. Artistik yüzme yarışma rutinlerinde teknik hareketlerle birlikte başarılı koreografi hazırlanmasında gereken unsurlar büyük önem taşımaktadır. Koreografi, temel ve yaratıcı hareketlerden oluşan bir dizi hareket grubunun bütünün içermektedir. Eşlik eden müzik ve koreografi içinde uyum bulunmaktadır (Danardani, Soegiyanto, Setijono ve Sulaiman, 2018). Genellikle yarışma koreografileri seçilen müziğin konusuna sahiptir.

Seçilen müzik ve koreografi konuları arasında bale eserleri büyük yer tutmaktadır. Başarılı koreografi uygulamasında müziğin etkili kullanımı ve konuyla ilgili hareket içerikleri artistik yüzme yarışma puanlamasında önemli unsurlardandır. Özellikle dünya çapında ün yapmış Kuğu Gölü, Uyuyan Güzel ve Don Quixote gibi klasikleşmiş balelerin yarışma koreografilerine uyarlandığı görülmektedir. Bu çalışmada dünyaca ünlü Don Quixote balesinin artistik yüzmeyle ilişkisi incelenmiştir. Don Quixote balesinin koreografi Marius Petipa ve bestecisi Ludwig (Léon) Minkus'tur. Marius Petipa balenin librettosunu Miguel de Cervantes Saavedra'nın aynı adlı romanından yola çıkarak hazırlamışıır. Bale 3 perde olarak ilk kez 1869 yılında sahnelenmiştir (Deleon, 1997; Durante, 2018). Bale eserlerinde kullanılan müzikler genel olarak birbiriyle uyumlu küçük bölümlerin arka arkaya eklenmesiyle oluşturulmaktadır. Pek çok balede olduğu gibi Don Quixote’ta da aynı yöntem izlenmiştir.

Bale eserlerinin artistik yüzmeye uyarlanmasında seçilmiş konu kısmen havuz ortamına aktarılmaktadır. Bunun başlıca nedeni yarışma kuralları, sporcuların cinsiyeti ve sporcu sayısı gibi temel farklilıkların belirtilmesinden kaynaklanmaktadır. Yarışma koreografilerinin hazırlığında teknik beceri, müzik ve artistik unsurlar ön plandadır (FINA, 2017; Sytchenko, 2019; Li, Xin, Wei, Hui ve Mei, 2020). Don Quixote balesi özelinde incelemesi yapılan bu çalışmayla yarışma rutinleri için gerekli olan artistik koreografi unsurlarının belirleneceği düşünülmüştür. Artistik yüzme sporu çok yönlü yapısından dolayı birkaç farklı alanda analiz çalışmasına ihtiyaç duymaktadır. Artistik yüzme koreografilerinin incelemesi, başarılı yarışma rutinlerinin hazırlanmasına yardımcı olan çalışmalardır.

\section{Araştırmanın Amacı}

Hazırlanan çalısma, tanınmış bale eserlerinden biri olan Don Quixote'un yarışma kurallarına bağlı kalarak artistik yüzme koreografisine uyarlanmasındaki unsurların incelenmesidir. Yapılan artistik yüzme incelemesinin örnek çalş̧ma niteliğinde olması amaçlanmıştır. Dünya şampiyonası seviyesinde yarışmış bir artistik yüzme koreografisinin aynı konulu bale eserine içerik ve uygulama bakımından benzerliğinin belirlenmesi hedeflenmiştir. 


\section{YÖNTEM}

Araştırma tarama modelinde artistik yüzme ve bale koreografileri videolarının gözlem yapılarak analiz edilmesi şeklinde hazırlanmıştır. Bu bölümde araştırmanın veri toplama araçları ve verilerin koreografik açıdan analizi hakkında aşağıdaki açıklamalara yer verilmiştir.

\section{Araştırma Grubu}

Araştırma evrenini konulu artistik yüzme yarışma koreografileri oluşturmaktadır. Araştırma grubu olarak bale konulu Don Quixote koreografileri belirlenmiştir. Seçilen bale eserinin belirlenmesinde iki temel özelliğe dikkat edilmiştir. Birinci özellik yaygın olarak dünya çapında tanınan bale eserlerinden birinin olması, ikinci özellik seçilen balenin artistik yüzme koreografilerinde yer almış olması gerekliliğidir. Bu iki özelliği taşıyan balelerden Don Quixote seçilerek gerekli koreografi incelemesi için videolar temin edilmiştir.

Artistik yüzme sporunda genel anlamda yarışmaları için solo, düet, karışık düet, takım, serbest kombinasyon ve highlight rutin olmak üzere toplam 6 farklı koreografi türü bulunmaktadır. Araştırmada kullanmak üzere serbest kombinasyon yarışma türü seçilmiştir. Serbest kombinasyon koreografisi yap1 itibariyle çeşitli uygulamalar içerebilen ve süre olarak en uzun yarışma olması nedeniyle tercih edilmiştir. $\mathrm{Bu}$ yarışma türü FINA kuralları nedeniyle sadece 10 kadın sporcudan oluşmakta ve koreografi yapısı bakımından içinde solo, düet, üçlü, dörtlü ve beşli gruplar oluşturulmasına imkân sağlayan bir özelliğe sahiptir.

Örneklem için dünya çapında ve kendi dallarında başarılı kabul edilen bir artistik yüzme yarışma performansı ile üç bale eseri performansı seçilmiştir. Artistik yüzme ve bale, canlı performans uygulamaları olduğu için resmi video kayıtları temin edilerek araştırma verileri hazırlanmıştır.

\section{Veri Toplama Araçları}

Veri toplamak için bale eseri incelemesinde farklı koreografi unsurlarını takip etmek amacıyla tablo 1'de yer alanlar performansların analizi yapılmıştır (American Ballet Theatre, 2020; Los Angeles Times, 2020; Mariinsky Theatre, 2020).

Tablo 1. İncelemesi Yapılan Üç Don Quixote Balesinin Temel Bilgileri

\begin{tabular}{clll}
\hline Sahnelenme Y1l & Koreografi & Güncelleyerek Sahne Koyan & Dans Eden Bale Topluluğu \\
\hline 1983 & Marius Petipa & Mikhail Baryshnikov'un artistik direktörlügünde & Amerikan Bale Tiyatrosu \\
1994 & $\begin{array}{l}\text { Marius Petipa } \\
\text { Alexander Gorsky }\end{array}$ & Yury Grigorovich & Bolshoi Tiyatrosu \\
2013 & $\begin{array}{l}\text { Marius Petipa } \\
\text { Alexander Gorsky }\end{array}$ & Bilgi verilmemiş & Mariinsky Tiyatrosu \\
\hline
\end{tabular}

Artistik yüzme yarışma koreografisi olarak Don Quixote balesini konu alan 2015 FINA Dünya Su Sporları Şampiyonası'nda Rusya Federasyonu sporcuları tarafından yapılmıs serbest kombinasyon final performansı seçilmiştir. Artistik yüzme yarışma performansı, FINA'nın şampiyona yayınlarını yaptığ1 resmi internet sitesinden izlenerek incelenmiştir (FINA, 2020). Artistik yüzme yarışma koreografisi Rusya Federasyonu ulusal takım antrenörleri tarafindan hazırlanmıştır.

\section{Verilerin Toplanması ve Analizi}

Veriler, süresine göre sürekli gözlem yapılarak toplanmıştır. Veri toplama aşamasında öncelikle bale müziği karşılaştırması yapılarak artistik yüzme koreografisine seçilen müzik bölümleri belirlenmiştir. Serbest kombinasyonun büyükler yaş grubunda yarışma süresi 4 dakikadır. Kural gereği 15 saniyelik eksiklik veya fazlalık kabul edilebilir özelliktedir (FINA, 2013). Yarısma koreografisi süresince hangi bale müziği bölümlerinin kullanıldığı belirlenmiştir. Koreografinin içindeki bölümler müzik değişimleri temel alınarak incelenmiştir. Buna göre Ludwig Minkus'un Don Quixote bale müziğinden artistik yüzme koreografisinde kullanılmış olan müziklerin genel özellikleri tablo 2'de yer almaktadır (Letellier, 2008). 
Tablo 2. Artistik Yüzme Koreografisinde Yer Alan Müziklerin Yapısal Özellikleri

\begin{tabular}{lllc}
\hline Müzik bölümünün adı & Temposu & Tonalite & Tartım \\
\hline Moreno & Presto & Sol (G) majör & $3 / 8$ \\
Quiteria (Kitri) ve Basilio & Andantino & Mi (E) minör & $6 / 8$ \\
Coda & Allegro vivace & Re (D) majör & $2 / 4$ \\
Kitri Varyasyonu & Allegro & Mi (E) bemol majör & $4 / 4$ \\
Pas de deux* Coda & Presto & Sol (G) majör & $2 / 4$ \\
\hline
\end{tabular}

*Pas de deux: İkili dans, iki kişi için dans (Grant, 1995).

Artistik yüzme koreografisinde bale eserinde yer alan 5 müzik bölümü kullanılmıştır. Bu nedenle yapılan koreografi beş bölüme ayrılarak analiz edilmiştir. Artistik yüzme koreografisi için iki analiz incelemesi yapılmıştır. Birinci analizde balede yer alan müziğe uygun konu bütünlügünün olup olmadığına bakılmış, ikinci analizde ise hareketlerin koreografi benzerliği incelenmiştir. Bale eserinin artistik yüzmeye uyarlanması hareket, mimik ve konu açısından Don Quixote balesi özelinde değerlendirilmiştir. Araştırmada görsel unsurlar ön plandadır. Bunun nedeni olarak artistik yüzme sporunun yarışma koreografisinin hareket yapısı bakımından incelenmesi ifade edilebilir.

\section{BULGULAR}

Bulguları oluşturan veriler, istatistiksel karşılaştırma yerine hareket yapılarının incelenmesi ve sanatsal öğelerin spora aktarımını ortaya koymaya yönelik hazırlanmıştır. İncelemesi yapılan artistik yüzme koreografisindeki müzik seçiminin Don Quixote balesindeki bölümlerle uyumlu olduğu görülmüştür. Seçilen müzik bölümleri orijinal yapısı bozulmadan kullanılmışıtır. Koreografide yer alan müzik bölümleri genellikle kesilmeden bölüm hâlinde alınarak kullanılmıştır. Seçilen müzikler sırasıyla Moreno, Quiteria (Kitri) ve Basilio, Coda, Kitri varyasyonu ve Grand Pas de Deux codası'dır. Müzik yapısı bakımından 1. perdenin sonunda kullanılan coda ve balenin son bölümde olan Grand Pas de Deux codası diğerlerine göre daha coşkulu ve hareketli türde uygulamalar içermektedir. Seçilen müziklerin tanınırlık özelliğine bakıldığında 4. ve 5. müzik bölümleri olan Kitri Varyasyonu ve Grand Pas de Deux codası diğerlerinden daha popülerdir. Sırasıyla Don Quixote konulu artistik yüzme koreografisini bölümleri aşağıda incelenmiştir. Bale eseri ve yarışma koreografisinin detaylı analizi için yöntemde açılandığı gibi bölümler müzik değişimleri temel alınarak yapılmıştır.

\section{Koreografi bölümleri}

Birinci bölüm: Artistik yüzme kuralları gereği sporcular suya atlamadan önce karada müziksiz 30 saniye ve müzikli 10 saniye koreografi hareketleri yapma hakkına sahip oldukları için artistik yüzme koreografisinin kara kısmında Don Quixote balesinde kullanılan bazı temel pozlar kullanılmıştır (Resim 1). Sporcular pozları 5 kişilik iki grupta belirli bir koreografi düzeninde uygulamıslardır.

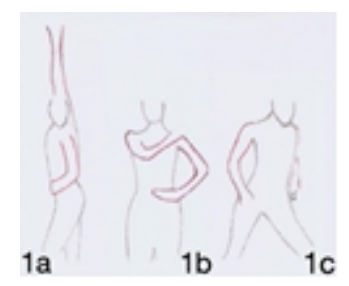

Resim 1. Artistik yüzme kara koreografisi için Don Quixote balesinden seçilen pozlar

Artistik yüzme koreografisi Moreno müziğiyle başlamışır. Müzik dansa hareketli ve coşkulu bir hava katmaktadır. Bale koreografisinde bu bölümde Kitri ve Basilio başrollerde dans ederken corps de ballet ${ }^{1}$ mimik, jest ve küçük hareketlerle dansçıları destekleyici performans sergilemektedir.

\footnotetext{
1 Corps de ballet: Bir balede, solist olmayan dansçılar (Grant, 1995). Birlikte dans eden özellikle baş dansçı olmayan bale dansçısı grubu (Cambridge Dictionary, 2020).
} 
Moreno dansının ilk bölümünde Kitri ve Basilio karşılıklı geçişmelerle zıt yöne aynı hareketi uygulama şeklinde performans sergilemektedir. Aynı zamanda ufak dönüşler ve karakteristik kol hareketleri görülmektedir. İspanyol karakter dans adımlarının olduğu bir bölümdür.

Moreno dansının ikinci bölümünde müzik aynı şekilde tekrar ederken kadın ve erkek dansçı arasında karşılıklı mimik içerikli hareketler yapılmaktadır. Devamında birinci bölümdeki geçişli karakter hareketler tekrar yapılmaktadır. Dansın üçüncü bölümünde kadın ve erkek dansçı beraber aynı hareketleri yan yana yapar ve sonunda birlikte dönüş yaptıktan sonra bitiriş pozu verirler. Hareket yapısı bakımından aksanlı ve noktalı kol pozisyonları koreografi boyunca uygulanmaktadır. İspanyol danslarda sık sık görülen karakteristik iki kol pozu resim 2 ve 3’te gösterilmektedir. Gösterilen kol pozlarının soldaki çizim örnekleri bale, sağdaki çizim örnekleri artistik yüzmeye uyarlanmış hâlini ifade etmektedir. Bacak hareketleri genel olarak karakter dans adımlarını içermektedir.

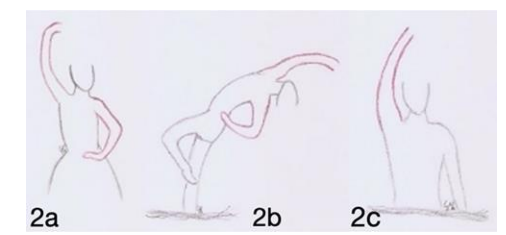

Resim 2. İspanyol konulu danslarda sık kullanılan kol pozisyonun bale ve artistik yüzme örneği

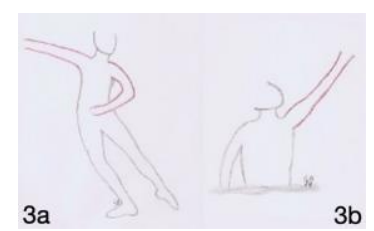

Resim 3. Karakter danslarda sık kullanılan kol pozisyonunun bale ve artistik yüzme örneği

Artistik yüzme koreografisinde sporcular suda ilk olarak akrobatik kaldırış hareketi uygulamıştır. Yukarı kaldırılan sporcu bale koreografisinde de kullanılan resim 2'deki kol pozisyonunu yapmıştır. Aynı kol pozisyonunun suya uyarlanmış versiyonu olan Rus ekolüne göre tek kol 3. bale pozisyonunda olan şekli tüm sporcular tarafindan bu bölümde kullanılmıştır. Sporcular hareketleri geçişmeli şekilde havuzda ilerleyerek yapmaktadır.

Tüm sporcuların aynı anda nefes aldığı bölümde yapılan tek kolun kullanıldığı pozisyon resim 3'teki pozdur. Bu kol pozunun baledeki örneği şekil 3’ün sol tarafında, artistik yüzme örneği ise sağ tarafinda yer almaktadır. Bacak hareketlerinde önce 7 sporcunun sonra diğer 3 sporcunun arka arkaya tek bacakla yaptığ1 serinin, balede sıklıkla kullanılan karşlıklı cevap verme hareketleri serisine denk düştüğü düşünülmektedir.

İlk bacak kaldırış hareketlerinde diz düz şekildeyken ikinci kaldırısta sporcular öne attitude ${ }^{2}$ hareketinin artistik yüzme versiyonunu yapmışlardır. Böylece balede sıklıkla kullanılan attitude hareketinin artistik yüzmede uygulandığı hâli görülmüştür. Resim 4'te attitude hareketinin Moreno müziği kısmında baledeki ve artistik yüzmedeki hâli sırasıyla resmin solunda ve sağında yer almaktadır. Artistik yüzme sporcularının koreografi gereği aynı anda su altına girmeleri gerekmiştir.

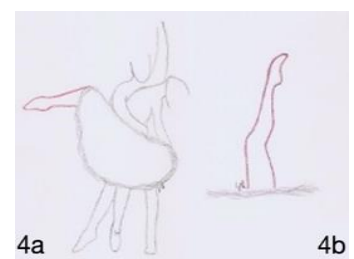

Resim 4. Attitude hareketinin Don Quixote balesinde ve artistik yüzmede kullanım örneği

\footnotetext{
2 Attitude: Bir bacak üstünde, diğer bacak doksan derecelik açıda havaya kaldırılmış, diz bükülü ve dışa dönük tutulmaktadır. Vücudun pozisyonlarına göre çeşitli attitude’ler yapılmaktadır (Grant, 1995).
} 
Suya batış sırasında sporcular bir kolu Rus bale ekolüne göre 1. pozisyonda, diğer kolu Rus bale ekolüne göre 3. pozisyona getirilmişs şekilde arkaya port de bras yapmışlardır. Bu pozun balede kullanılan kol pozisyonuyla aynısı olduğu görülmüştür.

Sporcular nefes alırken genellikle tek kol pozisyonda duruş yapmaktadır. Kol pozisyonları Don Quixote balesinde corps de ballet'nin yaptı̆̆ jest ve mimiklere benzemektedir. Sporcular çift kol boost hareketi yaparak nefes aldıklarında Rus bale ekolündeki 3. pozisyonunu uygulamışır. Koreografideki maksimal boost ve küçük boost hareketleri dikkatli izlendiğinde balenin temel özelliği yansıtılmıştır. Moreno müziğinin baledeki bölümünde Kitri ve Basilio beraber dönüş hareketi yaparken, suda sporcular arka arkaya geçişmeli su altından destekli ufak akrobatik kaldırışlar yapmıştır. Müzik bitişi balede pozla yapılırken, artistik yüzmede 5 sporcu tek kol maksimal boost yapmış diğer 5 sporcu da aralarından birini suyun dışına akrobatik hareketle firlatmıştır.

İkinci bölüm: Kitri ve Basilio birbirlerine sevgilerini ifade ederek pas de deux türünde dans ederler. Müzik yapısında vals karakteri hissedilmektedir. Bu bölümün sonunda müzik temposunda ani hızlanmalar göze çarpmaktadır. Kullanılan müzik düet yapısında dans etmeyi içermektedir.

Genel etki bakımından Macar halk danslarından Czárdás'a benzer özelliktedir (Letellier, 2008). Balenin koreografi bakımından ilk bölümünün yavaş, son bölümün ise hızlı dans hareketlerinden oluştuğu gözlemlenmiştir. Artistik yüzme koreografisi ise bir sporcunun solo performansıyla başlamıştır. Aynı bale eserlerinde olduğu gibi solo yapan sporcu ortada, diğer sporcular 4 ve 5 kişilik iki grup hâlinde ortadaki sporcunun sağında ve solunda konumlanmıştır. Bu durum aynı bale olduğu gibi solist dansçı ve corps de ballet uygulamasına benzemektedir. Solo koreografisi yapılırken diğer sporcular balenin klasik yapısında olduğu gibi basit hareket, mimik ve jestlerle uyum sağlamaktadır. Bazı hareketlerde farklı yönlerde duran sporcular solo yapan sporcuyla birlikte aynı hareketi yapmış ve kenarda duran bu iki grup arasında sırayla karşılıklı konuşma tarzında etkileşim ortaya çıkmıştır. Bu koreografi uygulamasında baledeki corps de ballet yapıs1 görülmüştür. Solo yapan dansçı artistik yüzme kuralları dahilinde özellikle kol hareketlerine bale koreografisini andıran hareket türleri yapmıştır. Bu müzik bölümünün sonuna doğru 8 sporcunun zıt kollarla aynı anda yaptı̆̆ ve diğer iki sporcunun birbirlerine bakarak aynı anda yaptığı maksimal boost hareketlerinde Don Quixote balesindeki karakteristik kol pozisyonlarının yapıldığı görülmüştür. Hareket pozları resim 1'deki ve Rus bale ekolündeki 1. ve 3. kol pozisyonlarını içermektedir. Müzik bölümünün sonunda 8 sporcu dördü önde dördü arkada çapraz duruş şekilde iki sırada makas hareketi yaparken kol ve baş pozları vermiştir. Ön sıradaki sporcuların verdiği poz, Don Quixote balesinde kullanılan karakteristik pozlardan biridir. Arka sıradaki sporcuların pozu ise koreografi uyumu açıdan ön sırayı tamamlayıcı niteliktedir.

Üçüncü bölüm: Neşeli bir atmosferde geçen coda bölümünde Kitri ve Basilio’le birlikte diğer solist dansçıların bazıları ve corps de ballet koreografi bütünlügünü koruyarak dans etmektedir. Müzikal coşkunun ve ritmin ön planda olduğu coda kısmında Seguidilla dansının müzik teması fark edilmektedir (Letellier, 2008). Müziğin sonuna doğru Kitri ve Basilio’in sahneden kaçtı̆̆ı, corps de ballet dansçılarının coşkulu danslarına devam ettiği ve Don Quixote'un beraberindekilerle mimik ağırlıklı karakteristik hareketler yaptığı görülmektedir. Bu müzik bölümü aynı zamanda balenin birinci perdesinin sonudur. Kullanılan bu müzik bölümünde artistik yüzme koreografisi için bazı yerlerin kısaltıldığı belirlenmiştir. Bale koreografisinde yapılan kol hareketleri resim 1, 2 ve 3'teki pozları içermektedir. Bale koreografisinde bu müzik bölümünde önce iki kadın dansçı dönüş ağırlıklı hareketler yapmış daha sonra corps de ballet dansçları dahil olmuştur.

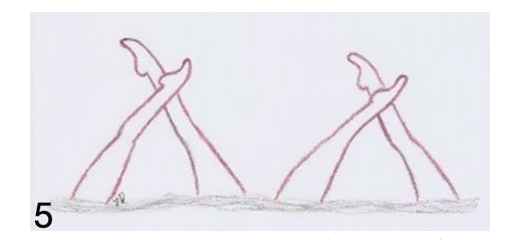

Resim 5. Dört sporcunun bacak serisi hareket örneği 
Artistik yüzme koreografisinde ise aynı müzikte 10 sporcunun tümü vertical tek bacak hazırlık pozu alarak öne arkaya çaprazlama bacak serisi yapmıştır. Resim 5'de bale koreografisinde dönüşlü hareketler yerine uygulanan bacak serisi örneği bulunmaktadır. Bacak serisi sporcuların 3-4-3 gruplu olacak şekilde dağılımıyla devam etmiştir. Bu gruplaşma balede corps de ballet ve toplu dansın örneği olarak düşünülmüştür. Don Quixote balesine benzer şekilde artistik yüzme koreografisinde çeşitli geçişler eklenerek müzikle uyumlu coşkulu bir koreografi yapılmıştır. Müzik bölümünün bitiş kısmında gösterişli ve teknik açıdan zor bir akrobatik kaldıış yapılmıştır. Aynı müziğin bale versiyonunda ise birinci perdenin sonu sahnelenirken özellikle corps de ballet’nin coşkulu dansı göze çarpmaktadır.

Dördüncü bölüm: Seçilen müzik bölümünü Grand Pas de Deux koreografisinin içinde yer alan Kitri solosu oluşturmuştur. Kadın dansçılar için uzmanlık gerektiren point tekniğinde dans edilen Kitri solosu oldukça popülerdir. Bu solo müziğinde arp sesi ön planda olmakla birlikte ritmik ve akıcı bir temponun varlı̆̆1 anlaşılmaktadır. Balede Kitri solosu olarak kullanılan bu müzik bölümünde artistik yüzme koreografisinin başlangıcı olarak düet ve yanlarda dörtlü iki grup yer almıştır. Solist ile corps de ballet'nin suya uyarlanmış hâli burada da mevcuttur. Artistik yüzme düet kategorisi temelde aynı anda iki kadın sporcunun hareketleri bir kişiymiş gibi yapmasını içermektedir. Bu nedenle Kitri solosunun düetle başlaması mantıklı bir uygulama olmuştur. Bale solosunda olduğu gibi müziğin başlangıç kısmı yavaş ve artistik hareketler içermektedir. Karadaki koreografide olduğu gibi teknik zorluk seviyesinin arttığı ve müziğin hızlanmaya başladığı kısımda düet yapan sporcular bacak serisi yaparak uyum sağlamıştır. Teknik açıdan karadaki bacak adımlarının suya uyarlanmasının bir örneği olarak düet bacak serisinin gösterilmesi mümkündür. Bacak serisinde hem akıc1 hem de seri şekilde geçişlerle birlikte bent knee, çift bacak vertical duruş türleri ve split geçişli varyasyonlar uygulanmıştır. Bu sırada diğer sporcular koreografi uyumu içinde basit hareket ve mimiklerle havuzda ilerleyerek yer değiştirmişlerdir. Düet bacak serisinden sonra başka bir sporcu benzer özellikte solo bacak serisi yapmıştır. Solo müziğin orta ve son bölümlerinde tüm sporcular üçlü, dörtlü ve beşli gruplar hâlinde değişerek hareketlerini uygulamıştır. Uyum açısından Kitri solo müzik bölümünün sadece ilk kısmının Don Quixote balesiyle benzerlik gösterdiği anlaşılmıştır. Geri kalan müzik kısımlarında koreografi bütününe uygun hareket ve geçişler yapılmıştır. Artistik yüzmenin teknik unsurları kullanılarak balede olan karşılıklı gruplar arasında hareketlerle konuşma özelliği yansıtılmıştır.

Beşinci bölüm: Don Quixote balesinin Grand Pas de Deux’sünün son bölümü olan coda kısmıdır. Konu olarak Kitri ve Basilio'in düğun kutlaması, geleneksel evlilik, dans ve eğlence içinde pas de deux tamamlanmaktadır. Müzikte coşkulu ve yükselip büyüyen melodi Coda'nın çoğu yerinde hissedilmektedir. Müzik akıcı ve hızlı bir yapıdadır. Balede koreografi yapısına göre Kitri ve Basilio rollerinin dansı yer almaktadır. Bu müzik bölümü artistik yüzme koreografisinin son bölümü oluşturmaktadır. Artistik yüzme koreografisinde ilk başlangıç bölümünde sporcular üçlü ve yedili iki grup hâlinde sırayla figürlerini yapmaktadır. Kol pozisyonu olarak Rus bale ekolü 3. pozisyonunun ağırlıklı olarak kullanıldığ1 görülmüştür. Tüm sporcular toplu olarak bazı kol hareketleri uygulamıştır. Koreografi boyunca kullanılan karakteristik Don Quixote kol poz ve hareketlerinin örnekleri resim 6'da verilmiştir. Bu hareketlerin müziğe uygun şekilde kesik kesik, net ve vurgu içeren pozları kapsadığ1 görülmüştür.

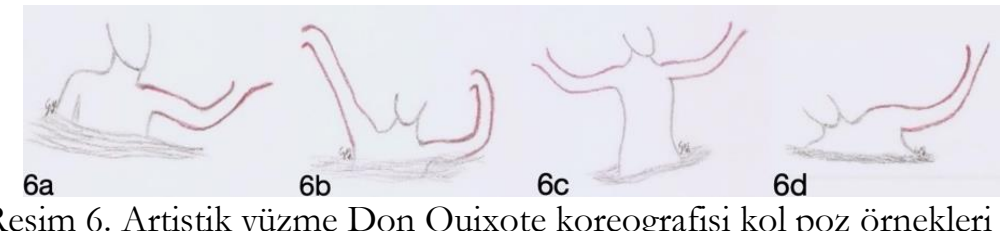

Kısa bacak serisi ve artistik geçişler sonrasında bitiriş bölümünden önce tekrar 3. kol pozisyonu yapılmıştır. Sporcuların kol pozisyonunun kullanımı artistik yerleşim şekline göre 3-4-3 şeklinde yapılmış ve 4 kişilik grubu oluşturan sporcular çift kol, diğer sporcular zıt kollarla tek kol yapmışlardır. Coda müziği ve tüm yarışma koreografisinin bitiriş hareketi teknik seviyesi yüksek akrobatik bir kaldırışla gerçekleşmiştir. Akrobatik kaldırış uygulaması baledeki tour en l’air (havada dönüş) hareketine benzemektedir. Tüm artistik 
yüzme koreografisinde yaygın olarak kullanılmış balenin 3. kol pozisyonu son harekette de uygulanarak koreografi bitmiştir.

\section{TARTIŞMA ve SONUÇ}

İncelenen artistik yüzme ve bale koreografileri sonucunda Don Quixote balesinin karakteristik yapısının nasıl aktarıldığı belirlenmiştir. Karada yapılan klasik bale eserinin suya aktarımındaki genel özellikler kısmen ortaya çıkmıştır. Bale müziğinin artistik yüzmede kullanılması durumunda, müzik bölümlerinin kesilmeden veya kısmen küçük bir kısmının çıkarılması konu bütünlüğü bakımından yararlı görünmektedir. Bale konusunun artistik yüzmede işlenmesi ve yarışma müzik süresine uyarlanırken bölümler arasındaki uyumun başarlı olması için doğru seçim yönteminin önemi ortaya çıkmıştır. Artistik yüzmede eşlik eden müzik, koreografi ve fiziksel yetenekler uyumlu şekilde bir form oluşturmaktadır. Yarışmalarda sadece sporcu sayısı değil aynı zamanda sporcuların performans süreleri ve koreografi koşullarında görülen farkll11klara dikkat edilmesi gerekmektedir (FINA, 2017; Danardani vd., 2018; Li vd., 2020). Müzik yapısının ve artistik yüzme yarışma süresinin koreografi açısından dikkat edilmesi gereken konular olduğu gözlemlenmiştir. Don Quixote bale eseri ve konusunun sporcu sayısına uygun müzikle desteklenmesi etkileyici bir performans ortaya çıkarmıştır. Balede olduğu gibi artistik yüzme yarışma koreografisi gösterişli bir müzikle başlamış, orta bölümde genelde yavaş ve sakin müzik ritimleri kullanılmış, son bölüm balenin etkileyici ve yaygın tanınan müzik bölümünü içeren kısmıla sona ermiştir.

Koreografi alanı zengin bir arena olarak ifade edilmektedir. Amaca uygun yaratıcı, çok yönlü, zihinsel imgeleme ve etkileşim içermektedir (Kirsh, Muntanyola, Jao, Lew ve Sugihara, 2009; Li vd., 2020). İhtiyaçlar doğrultusunda sistemli hazırlık çalışmaları gerektirmektedir. Koreograflar dans yaratırken genellikle dansçıların bedensel özelliklerine uygun hareket formları geliştirmektedir. Koreografilerde dikkatli gözlem ve analiz yoluyla yaratıcılığın çok yönlü etkileşim biçimi ortaya çıkmaktadır (Kirsh vd., 2009). Antrenörler sporcuların özelliklerine uygun şekilde koreografileri somutlaştırmaktadır (MuntanyolaSaura, 2015; FINA, 2017). Artistik yüzme koreografileri hazırlanırken sporcuların hem atletik özellikleri hem de sanatçı yönlerinin ortaya çıkarılmasına özen gösterilmektedir. Bale eserlerinde kullanılan temel hareket ve esere özgü karakteristik pozların artistik yüzmeye aktarımı sırasında kol pozlarının yaygın olarak kullanılabildiği gözlemlenmiştir. Artistik yüzme sporu uygulanışı gereği bazı kısıtlamalar içermesine rağmen baleden aktarılan kol hareketleri ve pozların çok az kıstllılkla yapılabilirliği sonucuna varılmıştır. Bacak hareketlerinin baledeki gibi uygulanamadığı, bunun nedeninin artistik yüzmede baş aşağı hareket etme özelliğinden kaynaklandığı görülmüştür. Attitude ve baledeki temel hareket yapılarının rahatlıkla kullanılabildiği görülmüştür. Dönüş içerikli bale hareketleri, suda müziğe uygun şekilde keskin ve aksanlı formdaki bacak hareketleriyle desteklenmiştir. Serbest kombinasyon koreografileri ile bale koreografileri benzer özellik içermesi bakımından karşılaştırılabilir niteliktedir.

Balenin konu bütünlügünü artistik yüzme koreografisine aktarmanın zorluğu görülmüştür. Yapılan çalışma doğrultusunda, Don Quixote balesinden bazı bölümlerin seçilerek serbest kombinasyon koreografisine uyarlanmasının daha doğru bir uygulama örneği olduğu anlaşılmıştır. Artistik yüzme yarışma koreografilerinde tüm bale eserinin konusunu anlatmak yerine içinden seçilmiş bir bölümün işlenmesinin daha etkili olacağı anlaşılmıştır. Bu tercihle anlatım daha netleşerek seçilmiş konunun yapısında bulunan temel hareket, poz ve mimikler etkili şekilde aktarılmıştır.

Sonuç olarak, bale eserlerinin kullanım alanlarından biri olan artistik yüzme sporu koreografilerinin hazırllğında detaylı bale bilgisine ihtiyaç vardır. Artistik duruş, poz ve mimik konularında bale eğitmenlerinden destek almanın önemi ortaya çıkmıştır. Detaylı bale bilgisine sahip olmak artistik yüzmenin sanatsal içeriğinde başarılı sonuçların alınmasını sağlayacaktır. Don Quixote balesi örneğinde olduğu gibi balenin artistik yüzme koreografisine uyarlanmasında müzik tercihi, karakteristik poz ve hareketlerin etkin kullanımı başarılı sonuç almaya katkı sağlamaktadır. Balenin etki alanını kapsayan mesleklerden biri olarak artistik yüzmenin kabul edilmesi mümkündür. Hazırlanan bu çalışmada bir kez daha görülmüştür ki; artistik yüzme koreografisi yapmak için baleden yararlanılması gerekmektedir. Bale 
konulu bir eserin artistik yüzmeye uyarlanması sırasında müzik seçimine, karakteristik kol ve bacak hareketlerine, anlık pozlara ve duyguları anlatan mimik canlandırmalarına dikkat edilmesi gerekmektedir. Günümüzde bale eserlerinin farklı alanlara etkisi sanat ve sporun orantılı şekilde harmanlanmış hâli olan artistik yüzme Don Quixote balesi örneğiyle açıklanmıştır.

\section{KAYNAKLAR}

American Ballet Theatre. (2020, 11 Aralık). Don Quixote. Erişim adresi: https://www.imdb.com/title/tt0273178/

Bespalov, B. I. ve Leonov, S. V. (2012). Characteristics of silent countingin synchronized swimmers. Psychology in Russia: State of the Art, 5(1), 498-510. doi: 10.11621/pir.2012.0031.

Cambridge Dictionary. (2020, 11 Aralık). Corps de ballet. Erişim adresi: https://dictionary.cambridge.org/tr/sözlük/ingilizce/corps-de-ballet

Danardani, W., Soegiyanto, K. S., Setijono, H. ve Sulaiman, M. (2018). Artistic swimming helps the intelligence development. In International Seminar on Public Health and Education 2018 (ISPHE 2018), 81-85. doi: 10.2991/isphe-18.2018.18.

Deleon, J. (1997). 200 Bale ve Dans: künyeler, konular, taribsel, koreografile ve elestirel notlar. İstanbul: Yap1 Kredi Kültür Sanat Yayıncilık.

Dilling, M. W. (1997). The sound of the games: music for the 1996 centennial olympics. Ethnomusicology, 41(2), 313-319. doi: $10.2307 / 852621$.

Durante, V. (2018). Ballet: The Definitive Illustrated Story. New York: DK Publishing.

FINA. (2013). FINA artistic swimming manual for judges, coaches \& referees 2013 - 2017. www.fina.org

FINA. (2017). FINA artistic swimming manual for judges, coaches \& referees 2017 - 2021. www.fina.org

FINA. (2020, 11 Aralık). World Championships Kazan 2015 Free Combination Final. Erişim adresi: https://www.finatv.live/en/competitions/kazan-2015/video/free-combination-final-sy-kazan-2015

Grant, G. (1995). Bale Sö̋lïüü. (Çev. İnci Kurşunlu). İstanbul: MitosBOYUT Yayınları.

Istel, E. (1927). The music in "Don Quixote". The Musical Quarterly, 13(3), 434-450. doi: 10.1093/mq/XIII.3.434.

Kirsh, D., Muntanyola, D., Jao, R. J., Lew, A. ve Sugihara, M. (2009). Choreographic methods for creating novel, high quality dance. Design and Semantics of Form and Movement Conference Proceedings. Taipei: Taiwan University, 188-195.

Letellier, R. I. (2008). The Ballets of Ludwig Minkus. Newcastle: Cambridge Scholars Publishing.

Li, L., Xin, X., Wei, M., Hui, D. ve Mei, P. (2020). Research on the action design of team artistic swimming. International Journal of Sports Science and Physical Education, 5(1), 5-9. doi: 10.11648/j.ijsspe.20200501.12.

Los Angeles Times. (2020, 11 Aralık). Bolshoi's Daring 'Quixote'. Erişim adresi: https://www.latimes.com/archives/la-xpm1996-10-28-ca-58623-story.html

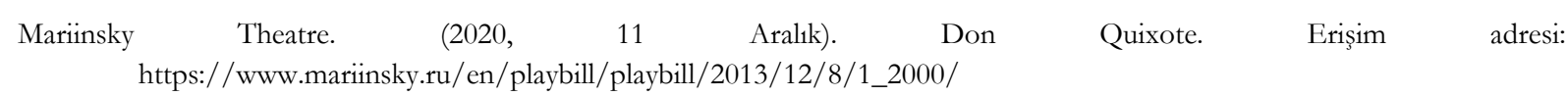

Muntanyola-Saura, D. (2015). Distributed marking in sport corrections: A conversation analysis of synchronized swimming. Journal of Cognitive Science, 16(3), 338-354. doi: 10.17791/jcs.2015.16.3.338.

Panebianco-Warrens, C. (2014). Exploring the dimensions of flow and the role of music in professional ballet dancers. Muriki, 11(2), 58-78. doi: 10.1080/18125980.2014.966480.

Pittsburgh Ballet Theatre. (2014). Don Quixote with The PBT Orchestra Audience Production Guide. USA.

Sydnor, S. (1998). A history of synchronized swimming. Journal of Sport History, 25(2), 252-267.

Sytchenko, K. V. (2019). Хореографія як важливий компонент у підготовці спортсменів в синхронному плаванні. Мистечтвознавчі записки, (35), 210-216. doi: 10.32461/2226-2180.37.2020 